\title{
A csilpcsalpfüzike (Phylloscopus collybita), a fitiszfüzike (Ph. trochilus) és a sisegö füzike (Ph. sibilatrix) vonulása a Dél-Tiszántúlon
}

\author{
BOZÓ LÁSZLó ${ }^{1 *}$ ÉS BOZÓNÉ BORBÁTH ERNA \\ ${ }^{1}$ Eötvös Loránd Tudományegyetem, Állatrendszertani és Ökológiai Tanszék, \\ 1117 Budapest, Pázmány Péter sétány 1/C E-mail: bozolaszlo91@gmail.com \\ ${ }^{2}$ Dél-békési Természetvédelmi és Madártani Egyesület, 5744 Kevermes, Jókai u. 61.
}

\begin{abstract}
Összefoglalás. Munkánk során a Magyarországon fészkelő füzikék tavaszi és őszi vonulását vizsgáltuk meg két dél-tiszántúli településen. Madárgyürüzési és terepi megfigyelési adatokat dolgoztunk fel a 2005-2018 közötti időszakból és a kapott eredményeket összehasonlítottuk más hazai kutatóállomásokról közölt publikációkkal. Eredményeink szerint ősszel a sisegö füzike és a csilpcsalpfüzike is később kezdi el vonulását, mint a tőlünk északabbra található földrajzi szélességeken. Mindhárom faj esetében megállapítottuk, hogy eltérések vannak a két vizsgálati helyen átvonuló madarak vonulási stratégiája között, aminek hátterében az eltérő minőségủ táplálkozási lehetőségek állhatnak. A terepi megfigyeléssel és a hálózással a legtöbb esetben különbözö vonulási intenzitást dokumentáltunk, ami azt mutatja, hogy ezen fajoknál a két különböző módszerrel gyüjtött adatok bizonyos esetekben eltérő eredményeket adhatnak. A fajok alapvetően hasonló élőhelyeken mozogtak a legnagyobb arányban, de a sisegő füzike gyakrabban használta a zártabb erdőt, mint a másik kettő.
\end{abstract}

Kulcsszavak: énekesmadár vonulás, Hódmezővásárhely, Kevermes, madárgyürüzés

\section{Bevezetés}

A Phylloscopus genus 77 tagja Eurázsiában, a délkelet-ázsiai és csendes-óceáni szigetvilágban, valamint Afrikában él (GILL \& DONSKER 2016; ALSTRÖM et al. 2018), melyek közül 3 faj Magyarországon is fészkel (MME NoMENClATOR BizOTTSÁG 2008). A csilpcsalpfüzike (Phylloscopus collybita) a gazdag cserjeszintü hegy-, domb- és síkvidéki lomberdők egyik leggyakoribb énekesmadara hazánkban, míg a fitiszfüzike ( $P$ h. trochilus) és a sisegő füzike (Ph. sibilatrix) fenyővel elegyes lombhullató erdőkben is megtelepszik, és azok hazai állománya jórészt az Északi-középhegység és a Dunántúl hegyvidéki területeire összpontosul (VARGA 1998a, 1998b, HARASZTHY 1998, MME NOMENCLATOR BIZOTTSÁG 2008). Vonuláskor országszerte nagy számban találkozhatunk velük fás-cserjés élőhelyeken és a vonulási időszakokban működő gyürüzőállomásokon is gyakran akadnak hálóba. Ennek megfelelően vonulásukról rengeteg információ áll rendelkezésünkre (LÖVEI 1983, CSÖRGÖ \& LÖVEI 1986, CSÖRGÖ et al. 1991, MIKLAY \& CSÖRGÖ 1991, GYURÁCZ et al. 2004, GYURÁCZ \& CSÖRGÖ 2009a, 2009b, 2009c, HARNOS \& CSÖRGÖ 2011). 
A csilpcsalpfüzikének jelenleg 5 alfaját különítik el (CLEMENT 2018a), amelyek közül a törzsalak $P$. c c collibyta költ, a $P$. c . abietinus szórványos tavaszi és őszi átvonuló, a $P$. $c$. trisis pedig ritka kóborló Magyarországon (MME NOMENCLATOR BIZOTTSÁG 2008). Kimutatták, hogy ősszel a madarak két időszakban vonulnak át a Kárpát-medencén (CSÖRGÖ et al. 1991, GYURÁCZ et al. 2004), ami nem populációs, hanem ivarok közti vonulási időzítésbeli különbségekre vezethető vissza (CSÖRGÖ \& LÖVEI 1986). Július-augusztusban a helyi madarak diszperziós mozgása figyelhető meg, míg a vonulás augusztus végén kezdődik, és október közepén tetőzik és november közepéig tart CsÖRGÖ et al. 1991, GYURÁCZ et al. 2004, GYURÁCZ \& CSÖRGÖ 2009a). Tavasszal február és május eleje között vonulnak át nálunk (CSÖRGÖ et al. 1991). A Kárpát-medencén kívül fészkelő madarak csak nagyon kis számban jutnak be annak területére, főként a vonulási időszak végén (LÖVEI 1983, GYURÁCZ \& CSÖRGÖ 2009a), így a Kárpát-medencében fészkelő populáció izoláltnak tekinthető (HARNOS \& CSÖRGÖ 2011). A Magyarországon átvonuló és az itt fészkelő madarak fö vonulási iránya dél-délkeleti, a hazai állomány telelőterülete Dél-Európában és Észak-Afrikában van (GYURÁCZ \& CSÖRGÖ 2009a).

A fitiszfüzike szintén politipikus, három alfajából kettő fészkel Európában (CLEMENT 2018b), melyek közül a törzsalak fészkelö, a $P$. t. acredula pedig szórványos átvonuló Magyarországon (MME NOMENCLATOR BIZOTTSÁG 2008). Vizsgálataink során elsősorban törzsalakhoz tartozó egyedeket fogtuk, de alkalmanként a $P$. $t$. acredula alfaj is hálóba akadt. A biometriai és visszafogási adatok alapján az észak-európai populációk egyedei a csilpcsalpfüzikéhez hasonlóan csak kis számban jutnak be a Kárpát-medencébe (MIKLAY \& CSÖRGÖ 1991). A nálunk átvonuló madarak délkeleti és délnyugati irányba is vonulnak, de a telelöterületekről visszafogások hiányában semmit sem tudunk (GYURÁCZ \& CSÖRGÖ 2009b). Őszi vonulásuk július végén kezdődik és október közepéig tart, míg tavasszal március vége és május eleje között vonulnak át hazánkon (GYURÁCZ \& CSÖRGÖ 2009b).

A sisegö füzike monotipikus faj (CLEMENT 2018c), Magyarországon az évente gyürüzött madarak száma ennél a fajnál a legkisebb (GYURÁCZ \& CSÖRGÖ 2009c). Az északi madarak többsége valószínüleg nem jut be a Kárpát-medencébe (MIKLAY \& CSÖRGÖ 1991), így a hazánkon ősszel július vége és szeptember, ill. tavasszal április eleje és május eleje között átvonuló példányok a medencén belüli állományokhoz tartozhatnak (GYURÁCZ \& CSÖRGÖ 2009c). A visszafogások alapján a hazánkban jelölt madarak az Appenninifélszigeten keresztül vonulnak déli irányba (GYURÁCZ \& CsÖRGŐ 2009c).

A három füzikefaj vonulását leíró cikkek (MIKLAY \& CSÖRGÖ 1991, GYURÁCZ \& BÁNHIDI 2008, MÓCSÁN 2008, GYURÁCZ \& CSÖRGÖ 2009a, 2009b, 2009c, HARNOS \& CSÖRGÖ 2011, Kiss et al. 2016) föként a bokros és erdős élöhelyeken müködő Actio Hungarica táborok adatsorain alapulnak, ezek közül azonban egy sincs az Alföld Tiszántúlon fekvő területén. Ha ehhez azt is hozzávesszük, hogy Románia Kárpátoktól nyugatra eső részén sincs állandó, standard körülmények között müködő madárgyürüző program, akkor gyakorlatilag egy több száz kilométer szélességben elnyúló adathiányos földrajzi részt kapunk. Munkánk során két, Dél-Tiszántúlon müködő madárgyürüző állomás adatait és terepi megfigyeléseket dolgoztunk fel az említett fajok vonulásának leírására. 


\section{Anyag és módszer}

Kutatásunkat a Dél-Tiszántúlon, Hódmezővásárhely és Kevermes településeken végeztük (1. ábra). Munkánk során a madárgyürüzés módszerét alkalmaztuk. A madarakat 7 és 12 méter hosszú japán típusú függönyhálókkal fogtuk meg, majd a fém jelölőgyürük felhelyezését követően különböző biometriai adatokat (szárnyhossz, testzsír, tömeg) vettünk fel róluk, meghatároztuk korukat, végül elengedtük öket.

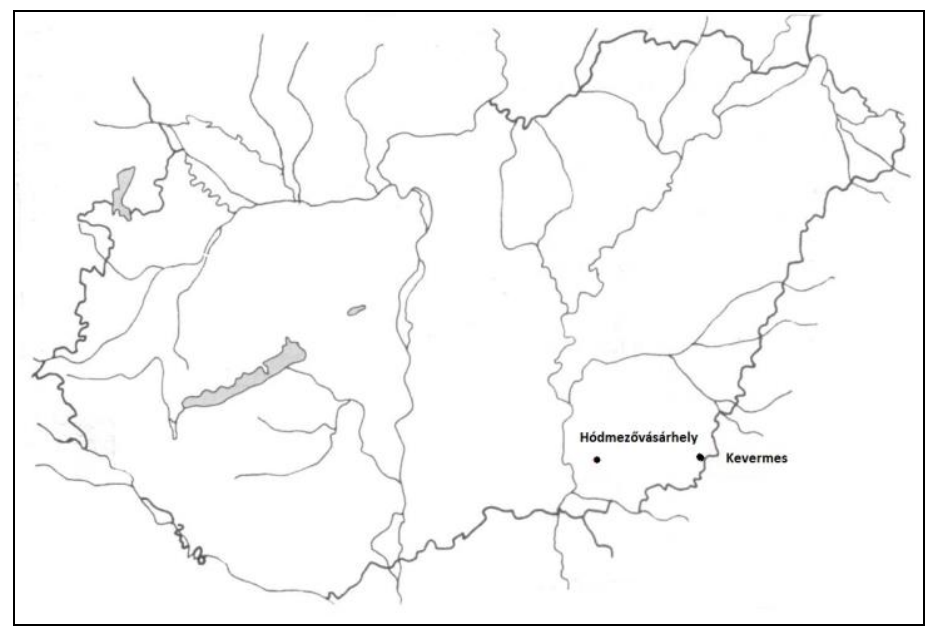

1. ábra. A kutatási területek országon belüli elhelyezkedése.

Figure 1. The location of the research areas within Hungary.

Kevermesen az egykori fácántelep helyén (EOV 815638 123876) lévő, hét hektár kiterjedésű ezüstfás (Elaeagnus angustifolia) erdő kb. 0,5 hektáros foltjában dolgoztunk. Alapvetően bokros élöhelyröl van szó, függetlenül attól, hogy több magas fa is fellelhető a területen. Az erdő átlagos magassága 3,5-4 méter, a domináns ezüstfa mellett néhány ennél magasabb szil (Ulmus sp.), akác (Robinia pseudoacacia) és vadkörte (Pyrus pyraster) is megtalálható itt elegyben. A cserjeszintet fekete bodza (Sambucus nigra) és kökény (Prunus spinosa) alkotja, míg az alsóbb szinteken gyakori a hamvas szeder (Rubus caesius). Az erdőszélen sürübb a növényzet, itt nádas és gyomos foltok is vannak. Közvetlenül az erdő mögött egy DK-ÉNY lefutású vízelvezető csatorna (Tulkán-csatorna) húzódik, amelynek partján kosárfonó füzek (Salix viminalis), fiatal diófák és nyárfák állnak, míg a parton és a mederben sürü nádas található. Jelentős mennyiségű víz a kutatás egyik éve alatt sem volt benne. 13 darab hálót helyeztünk el a területen, amelyek közül négy a csatornában, kilenc pedig az erdőben állt. A két élőhelytípusnál közölt megfogási százalékok a nyers adatok, a két élőhelytípus közötti nem egyenlő megosztással nem lettek súlyozva az 
eredmények. A munka 2016-ban, 2017-ben és 2018-ban is augusztus első és október utolsó hete között zajlott, évente 208 munkaórán keresztül. Tavaszi gyürüzés egyik évben sem volt, mivel a területen november elejétől április végéig apróvadra, ill. őzre vadásztak.

Hódmezővásárhelyen a Téglagyári tavak területén gyürüztünk (EOV 749638 121707), ahol a 19-20. században agyagot bányásztak, majd a vízzáró rétegek átvágásával a gödrök elkezdtek feltöltődni. A nagyobb, mélyebb tavak nyílt vizüek maradtak, míg a kisebb, sekélyebb víztereket nád társulás (Phragmitetum communis) borítja. Nádas élőhelyen összesen négy háló került kihelyezésre. Azokban a gödrökben, amelyekben a vízzáró réteget nem vágták át, sủrü bozótos alakult ki, melynek domináns faja a keskenylevelü ezüstfa. Mellette nagy arányban található még gyepürózsa (Rosa canina), veresgyürüs som (Cornus sanguinea), kökény, közönséges fagyal (Ligustrum vulgare), cseresznyeszilva (Prunus cerasifera), kőris (Fraxinus sp.), szil, hamvas szeder, komló (Humulus lupulus), helyenként fehér akác, fekete bodza, egybibés galagonya (Crataegus monogyna) és lepényfa (Gleditsia triacanthos). Ezek a fajok keverten fordultak elő az egész területen, és hálóhelyeket a növényzet zártsága alapján lehet csoportosítani. Ez alapján öt háló a zárt, erdősebb, míg öt a nyílt, cserjés élőhelyekre lett felállítva. Az egyik hálóhely melletti növényzet átmenetet képzett a nádas és a cserjés között. A munka tavasszal március közepe és május vége, míg ősszel július vége és november közepe között zajlott 2011-2014 között. Ez alól 2012 márciusa és áprilisa a kivétel, amikor a központi gyürüzési engedély hiányában nem lehetett gyürüzni. Hét naponta egy teljes napon keresztül dolgoztunk, ami tavasszal 88, összel 216 munkaórát jelentett. Mivel július 31. és augusztus 7. között a hét minden napján szét voltak húzva a hálók, ezért az ekkor fogott madarak számát átlagoltuk (napi átlag) az összehasonlithatóság érdekében. A területről és terepi módszerekről további információkat BORBÁTH (2015) közöl.

A gyürüzési adatok mellett Kevermes teljes területéről, a 2005. január és 2018. június közötti időszakból származó terepi megfigyelési adatokat is közlünk. A kutatási terület részletes ismertetését Bozó (2017) adta közre.

Dolgozatunkban a csilpcsalpfüzike, a fitiszfüzike és a sisegő füzike tavaszi és őszi vonulási időszakát, testzsír- és tömeg változását vizsgáltuk és hasonlítottuk össze a hazai irodalomban szereplő eredményekkel (MIKLAY \& CsÖRGÖ 1991, GYURÁCZ \& BÁNHIDI 2008, GYURÁCZ \& CSÖRGÖ 2009a, 2009b, 2009c, HARNOS \& CSÖRGÖ 2011, KISS et al. 2016). A vonulás leírására a különböző paraméterek (első és utolsó madarak fogási dátuma, intenzív vonulás kezdete és vége, vonulási csúcs) medián értékeit adtuk meg. Intenzív vonulás kezdetének azt a dátumot tekintettük, amikortól a fogott madarak heti száma csilpcsalpfüzike és fitiszfüzike esetén meghaladta a 10 példányt. Sisegő füzike esetében csak a vonulási csúcs van megadva, mivel a heti fogásszám alapján az előbbihez hasonló intenzív vonulási periódust nem lehetett meghatározni. Vonulási csúcs a legmagasabb fogásszámú hetet/időszakot jelenti. Munkánk során a madarakról felvett adatok közül a testzsírt és testtömeget használtuk fel. A testzsír egy $0-8$-as skálán változik, ahol 0 azt jelenti, hogy a madár alsótestén a tollakat megfújva nem látszik a bőr alatt zsírpárna, míg a 8-as kategória esetében a zsír kiterjedése olyan mértékủ, hogy az a szegycsontot és a mellizomzatot is elfedi. A többi érték a zsír kiterjedésének mértékétől függően változott a két szélsőérték között. Kiszámítottuk, hogy változtak-e a madarak ezen paraméterei a vonulási időszakon belül az idő elörehaladtával. Ehhez lineáris regresszió analízist, míg a visszafogott madarak testzsír változásának elemzésénél páros t-próbát alkalmaztunk. A visszafogási adatokból minimális 
tartózkodási időt számoltunk. Megnéztük, hogy átlagosan mikor kezdődött el és ért véget a madarak vonulása, mikor fogtuk az első és az utolsó egyedeket. Megnéztük továbbá, hogy a madarakat milyen arányban fogták a különböző típusú élőhelyekre kihelyezett hálók.

A statisztikai számításokhoz a PAST statisztikai programot (HAMMER et al. 2001) és a Microsoft Excel 2013 programot használtuk.

\section{Eredmények}

\section{Csilpcsalpfüizike}

Tavasz

Hódmezővásárhelyen 70 madarat gyűrüztünk és két visszafogásunk volt (1. táblázat). A három tavaszi szezon közül a 2013-as fogásszáma jelentősen nagyobb volt, mint a másik kettőé. Az első madarak megfogásának mediánja március 19-én (legkorábban 2014. március 15-én, legkésőbb 2013. március 23-án), míg a vonulás befejezésének mediánja április 18-án volt (legkorábban 2013. április 14-én, legkésőbb 2011. április 23-án). A vonulás mediánjainak átlaga április 6-ra esett. A vonulás csúcsa április elején volt (2. ábra).

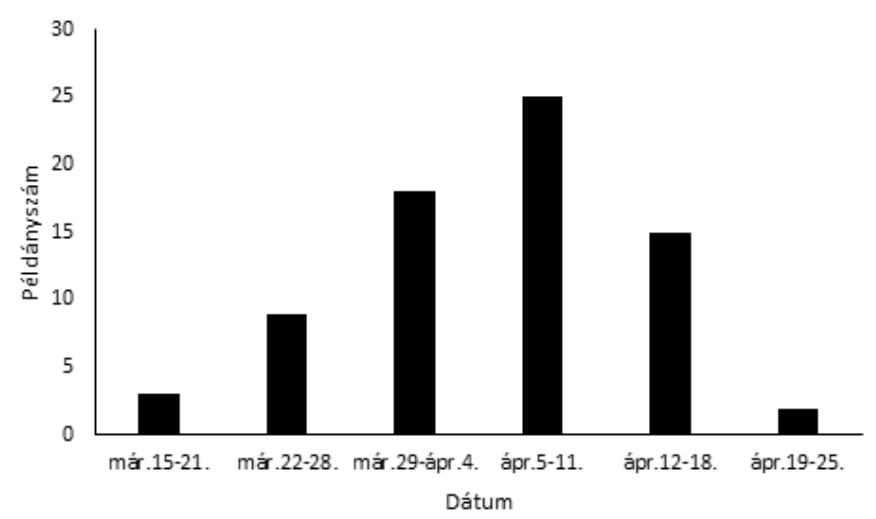

2. ábra. A csilpcsalpfüzike tavaszi vonulásdinamikája Hódmezővásárhelyen (kumulatív adatok).

Figure 2. Spring migration dynamics of Common Chiffchaffs in Hódmezővásárhely (cumulative data).

A két visszafogott madár egy, ill. öt napot töltött a területen.

A madarak testzsírjának mediánja 1 ( $\mathrm{SD}=0,88)$, míg átlagos testtömege $8,0 \mathrm{~g}(\mathrm{SD}=0,85)$ volt. A testzsír esetében azt figyelhettük meg, hogy a 0 zsírkategóriájú madarak aránya negatív korrelációt mutatott az idő múlásával $\left(\mathrm{R}^{2}=-0,4762\right)$, míg az 1-3 kategóriákba tartozó madarak aránya pozitívan korrelált vele $\left(\mathrm{R}^{2}=0,4761\right)(3$. ábra). A testtömeg és az idő között 
nem volt korreláció $\left(R^{2}=0,0046\right)$ (4. ábra). A legtöbb madarat (a teljes fogás $47,2 \%$-a) a bokros élöhelyen álló hálók fogták.

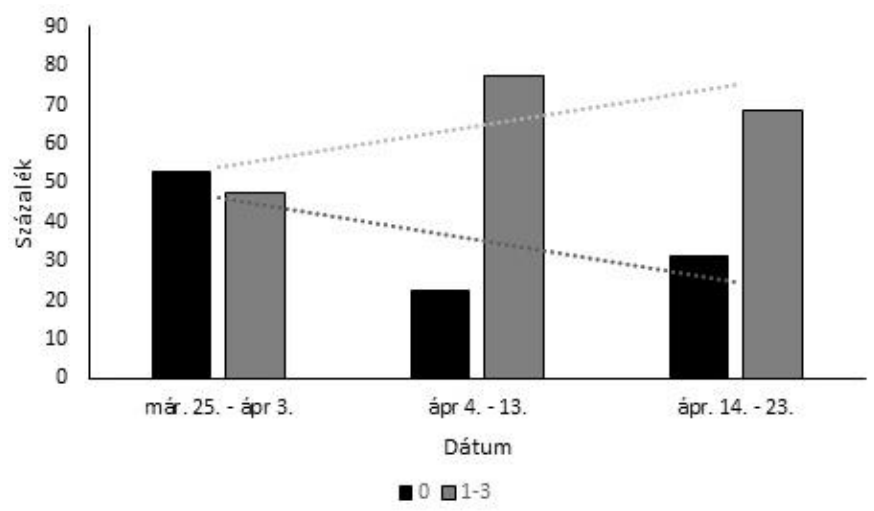

3. ábra. A csilpcsalpfüzike testzsírjának időbeli változása Hódmezővásárhelyen a tavaszi vonulási időszakban.

Figure 3. Changes of fat score values related to the date in Common Chiffchaffs during spring migration in Hódmezövásárhely.

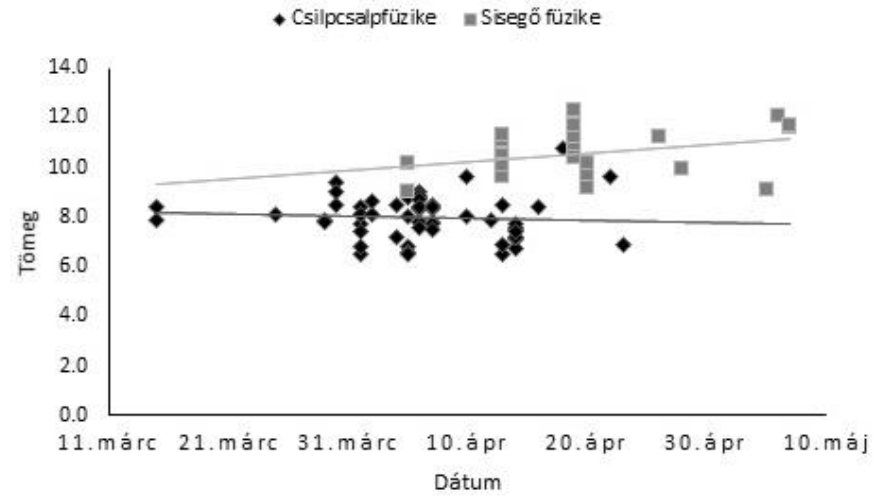

4. ábra. A csilpcsalpfüzike és a sisegő füzike testtömegének időbeli változása Hódmezővásárhelyen a tavaszi vonulási időszakban.

Figure 4. Changes of body mass related to the date in Common Chiffchaffs during spring migration in Hódmezővásárhely. 
A FÜZIKÉK VONULÁSA A DÉL-TISZÁNTÚLON

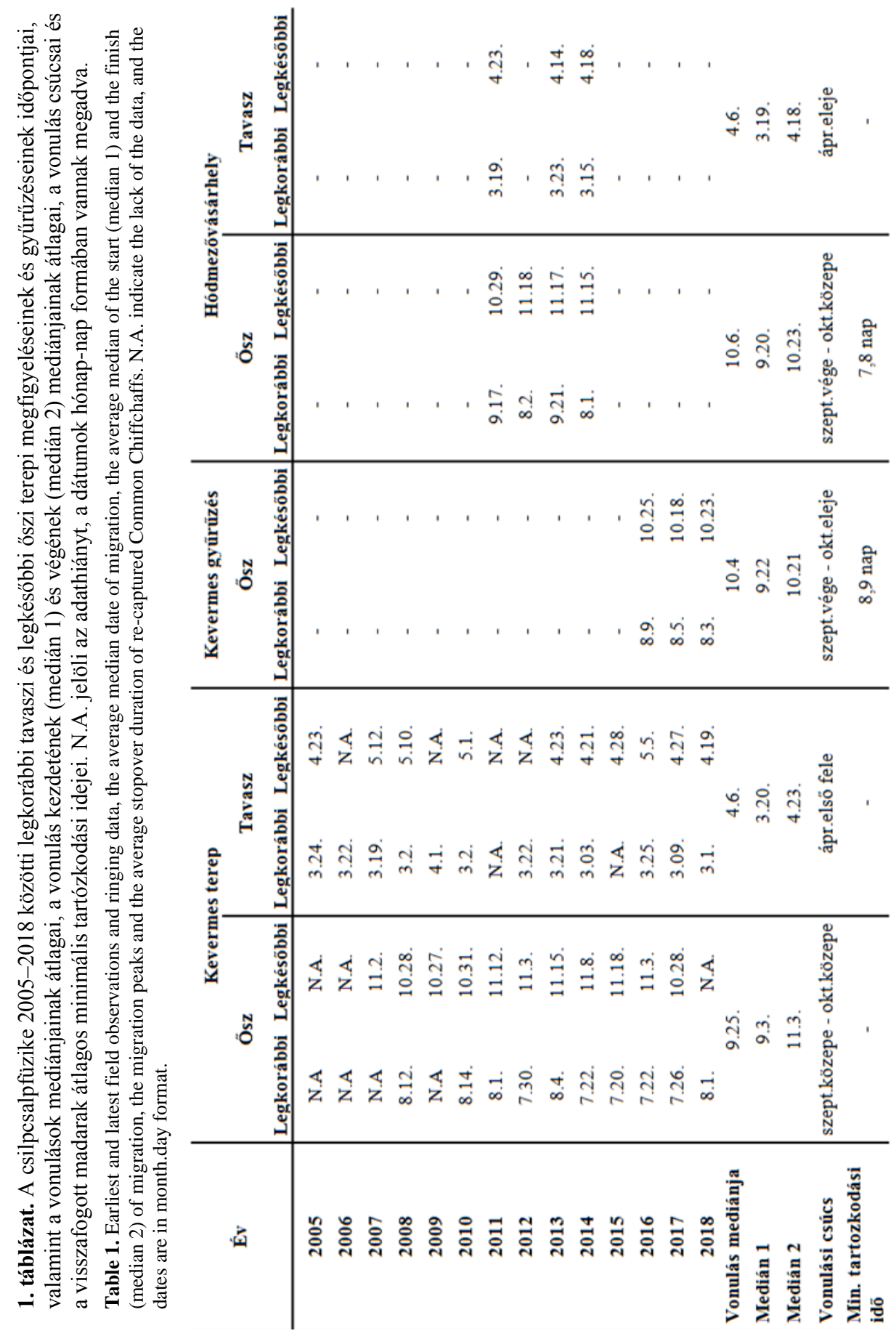


Ösz

Kevermesen összesen 317 madarat gyürüztünk és 49 visszafogásunk volt (1. táblázat). A három év alapján a vonulás mediánja október 4-én volt. Az első madarak megfogásának mediánja augusztus 5-én volt, de a madarak száma szeptember második feléig mindhárom évben viszonylag alacsony volt. Az intenzív vonulás kezdetének mediánja szeptember 22én, míg a vége október 21-én volt. A legkésőbbi gyürüzés 2017. október 25-én történt. A vonulási csúcs a három év alapján szeptember végén és október elején volt (5. ábra).

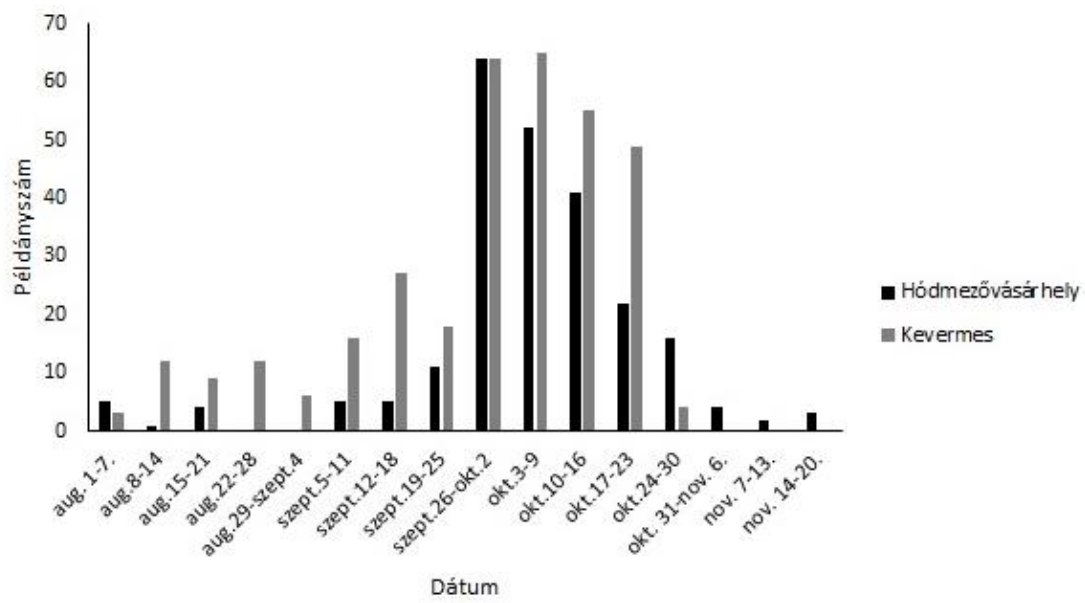

5. ábra. A csilpcsalpfüzike őszi vonulásdinamikája Hódmezővásárhelyen és Kevermesen (kumulatív adatok).

Figure 5. Autumn migration dynamics of Common Chiffchaffs in Hódmezővásárhely and Kevermes (cumulative data).

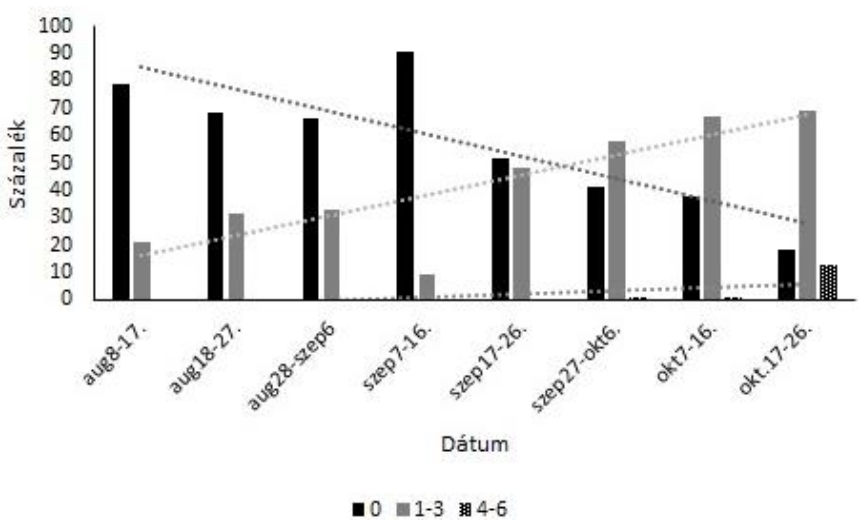

6. ábra. A csilpcsalpfüzike testzsírjának időbeli változása Kevermesen az őszi vonulási időszakban.

Figure 6. Changes of fat score values related to the date in Common Chiffchaffs during autumn migration in Kevermes. 
A visszafogott madarak aránya a három év során $12,4 \%, 15,3 \%$ és $12,8 \%$ volt. A visszafogott madarak minimális tartózkodási ideje 1 és 37 nap között változott, átlagosan 8,9 nap volt. A visszafogott madarak testzsírja és testtömege sem változott szignifikánsan az itt töltött idő alatt (páros t-próba, $\mathrm{p}>0,05$ ). A testzsír esetében azt figyelhettük meg, hogy a 0 zsírkategóriájú madarak aránya erős negatív korrelációt mutatott az idő múlásával $\left(\mathrm{R}^{2}=-0,7117\right)$, míg az 1-3 és a 4-6 kategóriákba tartozó madarak aránya pozitívan korrelált vele $\left(R^{2}=0,6926\right.$ ill. $\left.R^{2}=0,3967\right)$ (6. ábra). A testtömeg és az idő között nem volt korreláció $\left(\mathrm{R}^{2}=0,0062\right)$ (7. ábra). A madarak testzsírjának mediánja $1(\mathrm{SD}=1,2)$, míg átlagos testtömege $7,4 \mathrm{~g}(\mathrm{SD}=0,79)$ volt. A legtöbb madarat (a teljes fogás $56,8 \%$-a) a csatornában álló hálók fogták.

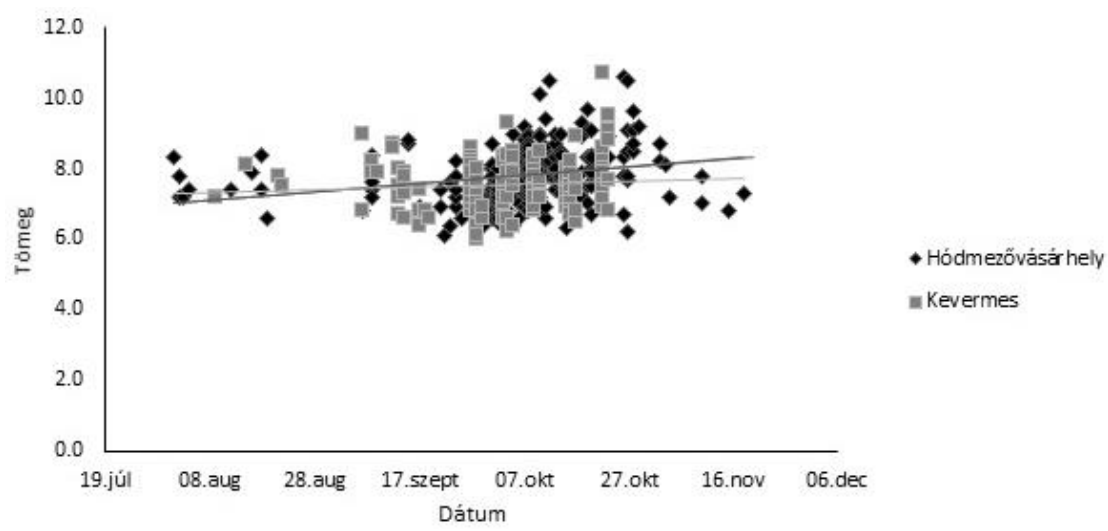

7. ábra. A csilpcsalpfüzike testtömegének időbeli változása Hódmezővásárhelyen és Kevermesen az őszi vonulási időszakban.

Figure 7. Changes of body mass related to the date in Common Chiffchaffs during autumn migration in Hódmezővásárhely and Kevermes.

Hódmezővásárhelyen 227 madarat gyürüztünk és 10 visszafogásunk volt (1. táblázat). Az intenzív vonulás kezdetének mediánja szeptember 20 -án, a vonulás befejezésének mediánja pedig október 23-án volt. A legkésőbbi gyürüzési adat 2012. november 18-ról származik. A vonulás mediánja október 6-án volt. A vonulás csúcsa szeptember legvége és október közepe között volt (5. ábra).

A visszafogott madarak aránya a különböző években 3,3\% és 6,5\% között változott. A minimális tartózkodási idő 1 és 21 nap között változott, átlagosan 7,8 nap volt. A testzsír esetében azt figyelhettük meg, hogy a 0 zsírkategóriájú madarak aránya negatív korrelációt mutatott az idő múlásával $\left(\mathrm{R}^{2}=-0,6712\right)$, míg az 1-3 és a 4-6 kategóriákba tartozó madarak aránya pozitívan korrelált vele $\left(\mathrm{R}^{2}=0,6231\right.$ ill. $\left.\mathrm{R}^{2}=0,3973\right)(8$. ábra). A testtömeg és az idő között nem volt korreláció $\left(\mathrm{R}^{2}=0,0612\right)$ (7. ábra). A visszafogott madarak testzsírja nem változott szignifikánsan az itt töltött idő alatt (páros t-próba, $\mathrm{p}>0,05$ ). A madarak testzsírjának mediánja $1(\mathrm{SD}=0,94)$, míg átlagos testtömege $7,8(\mathrm{SD}=0,76) \mathrm{g}$ volt. A legtöbb madarat (a teljes fogás 55,7\%-a) a bokros élőhelyen álló hálók fogták. 


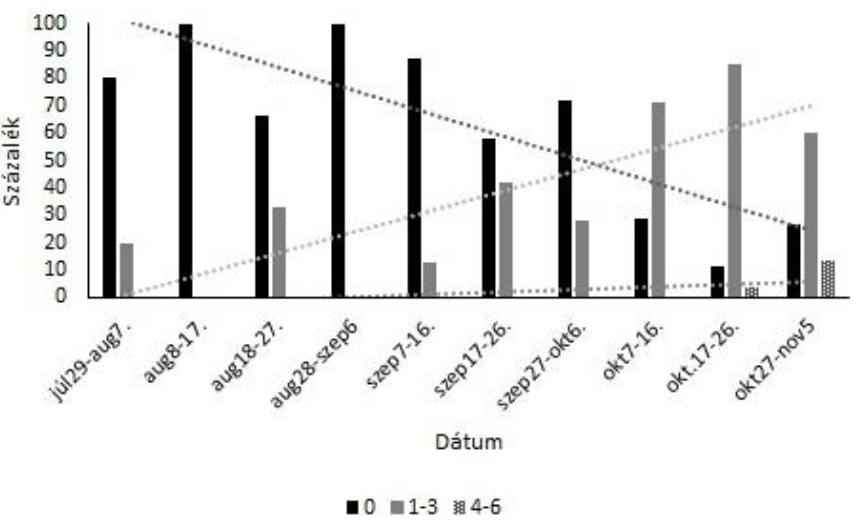

8. ábra. A csilpcsalpfüzike testzsírjának időbeli változása Hódmezővásárhelyen az őszi vonulási időszakban.

Figure 8. Changes of fat score values related to the date in Common Chiffchaffs during autumn migration in Hódmezővásárhely.

\section{Terepi adatok (Kevermes)}

Összesen 486 adat van a területről a 2005-2018 közötti időszakból. 2005-2018 közötti legkorábbi és legkésőbbi adatait az 1. táblázat tartalmazza. 12 év adatai alapján a tavaszi visszaérkezés mediánja március 20-án (legkorábban 2014. március 3-án, legkésőbb 2015. április 1-jén). A tavaszi vonulás befejezésének mediánja a 2013-2018 közötti adatok alapján április 23-án volt (legkorábban 2018. április 19-én, legkésőbb 2016. május 5-én). A tavaszi vonulás mediánja április 6-án, csúcsa április első felében volt. Márciusban egyik megfigyelési napon sem volt 10 példánynál több. A július második felétől augusztus végéig olykor nagy számban megfigyelt egyedek a helyi állomány tagjai lehetettek, mivel ekkor csak a fészkelöhelyeken történtek megfigyelések.

Az intenzív őszi vonulás kezdetének mediánja a 2012-2018 közötti adatok alapján szeptember 3-án volt (legkorábban 2016. augusztus 25-én, legkésőbb 2012, 2014 és 2015. szeptember 7-én). Az őszi vonulás mediánja szeptember 25-én, csúcsa szeptember közepe és október közepe között volt. Az őszi vonulás befejezésének mediánja 11 év alapján november 3-án volt (legkorábban 2009. október 27-én, legkésőbb 2012. november 30-án).

Egy téli megfigyelése történt 2012. január 2-án.

\section{Fitiszfüzike}

Tavasz

Hódmezővásárhelyen 5 madarat gyürüztünk, visszafogásunk nem volt. Legkorábban 2013. április 13-án, legkésőbb 2011. május 7-én fogtuk a fajt. Az alacsony mintaelemszám miatt nem lehet vonulási csúcsot meghatározni és a testzsír- és tömeg adatok elemzése sem volt lehetséges. A vonulás mediánja április 21-én volt. A madarak testzsírjának mediánja 1 $(\mathrm{SD}=1,1)$, míg átlagos testtömege $9,3 \mathrm{~g}(\mathrm{SD}=0,92)$ volt. 
Ösz

Kevermesen összesen 361 madarat gyürüztünk és 43 visszafogásunk volt (2. táblázat). A három év alapján a vonulás mediánja szeptember 12-én volt. Az első madarak megfogásának mediánja augusztus 4-én volt, de a madarak száma augusztus végéig mindhárom évben egyaránt alacsony volt (igaz 2018-ban a másik két évnél több madár akadt hálóba augusztusban is). Az intenzív vonulás kezdetének mediánja szeptember 1-jén, míg a vége szeptember 28-án volt. A legkésőbbi gyürüzés 2016. október 18-án történt. A vonulási csúcs a három év átlaga alapján szeptember első dekádjában volt (9. ábra).

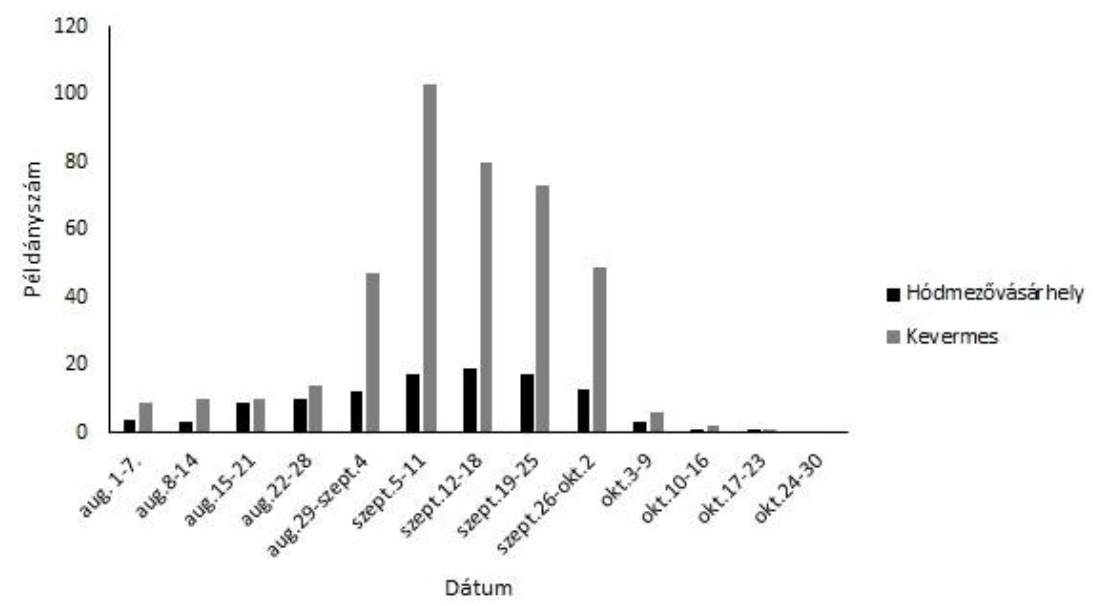

9. ábra. A fitiszfüzike őszi vonulásdinamikája Hódmezővásárhelyen és Kevermesen (kumulatív adatok).

Figure 9. Autumn migration dynamics of Willow Warblers in Hódmezővásárhely and Kevermes (cumulative data)

A visszafogott madarak aránya a két év során $5,1 \%, 7 \%$ és $13,6 \%$ volt. A visszafogott madarak minimális tartózkodási ideje minimum 1, maximum 28 nap, átlagosan 4,9 nap volt. A visszafogott madarak testzsírja és testtömege sem változott szignifikánsan az itt töltött idő alatt (páros t-próba, p>0,05). Szezonon belül a testzsír értéke és az idő között öszszességében nem volt sem pozitív, sem negatív kapcsolat (10. ábra), mint ahogy a testtömeg és az idő között sem volt korreláció $\left(\mathrm{R}^{2}=0,0269\right)(11$. ábra). A madarak testzsírjának mediánja $2(\mathrm{SD}=1,73)$, átlagos testtömegük $9,9 \mathrm{~g}$ volt $(\mathrm{SD}=1,73)$. A legtöbb madarat (a teljes fogás $40 \%$-a) a csatornában álló hálók fogták.

Hódmezővásárhelyen 111 madarat gyürüztünk és 2 visszafogásunk volt (2. táblázat). A vonulás kezdetének mediánja augusztus 26-án volt, de rendkívül nagy különbséget mutatott az évek közt (legkorábban 2012. augusztus 2-án, legkésőbb 2014. szeptember 6-án), míg a vonulás befejezésének mediánja október 9-én volt. A legkésőbbi gyürüzési adat 2013. október 19-ről származik. A vonulás mediánja szeptember 11-én volt. A vonulás csúcsa szeptember közepén volt (9. ábra). 
BOZÓ L. \& BOZÓNÉ BORBÁTH E

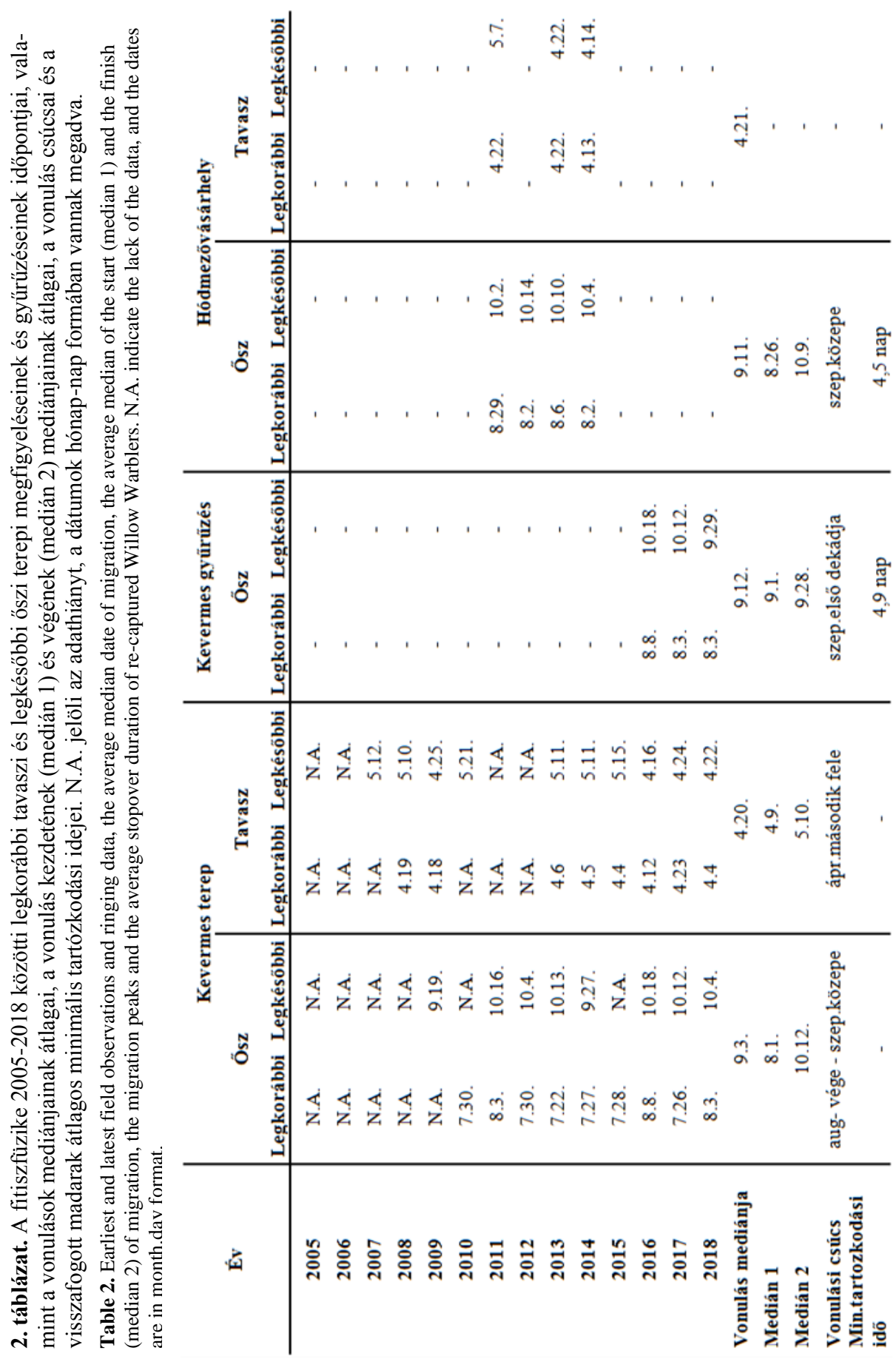




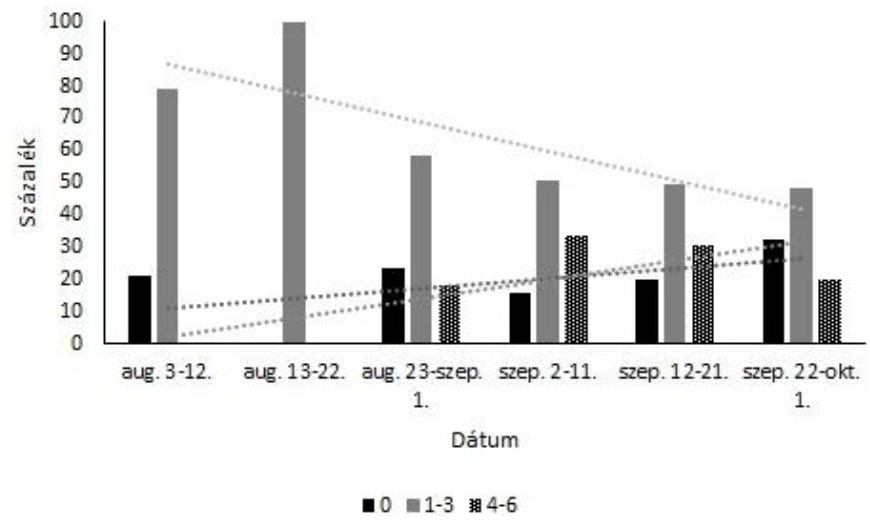

10. ábra. A fitiszfüzike testzsírjának időbeli változása Kevermesen az őszi vonulási időszakban.

Figure 10. Changes of fat score values related to the date in Willow Warblers during autumn migration in Kevermes.

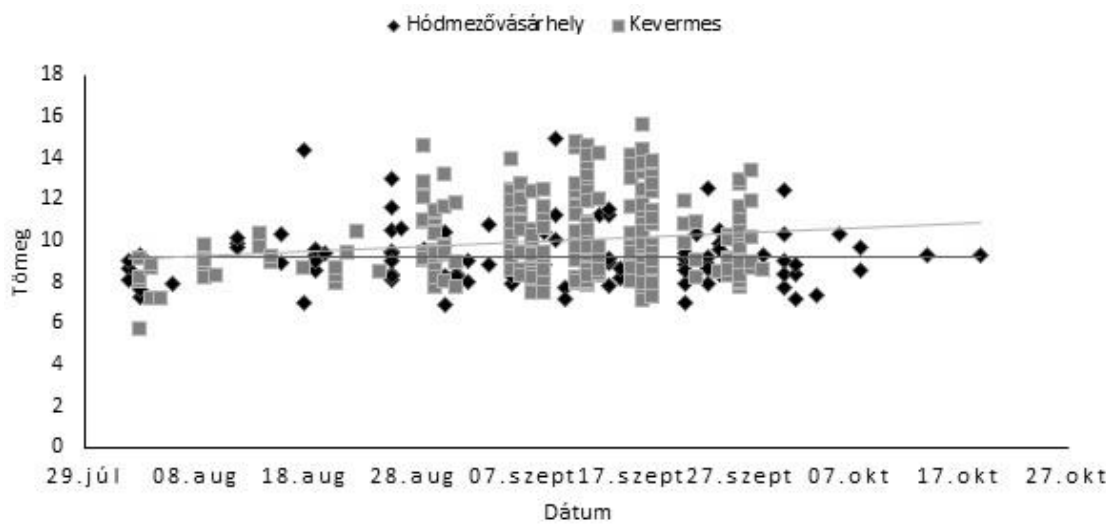

11. ábra. A fitiszfüzike testtömegének időbeli változása Hódmezővásárhelyen és Kevermesen az őszi vonulási időszakban.

Figure 11. Changes of body mass related to the date in Willow Warblers during autumn migration in Hódmezővásárhely and Kevermes.

A visszafogott madarak aránya 0 és 4,8\% között változott. A minimális tartózkodási idő 1 és 8 nap között változott, átlagosan 4,5 nap volt. A visszafogott madarak testzsírja és testtömege sem változott szignifikánsan az itt töltött idő alatt (páros t-próba, $\mathrm{p}>0,05$ ) Szezonon belül a testzsír értéke és az idő között összességében nem volt sem pozitív, sem negatív kapcsolat (12. ábra), ugyanakkor meg kell jegyezni, hogy a 4-6 zsírkategóriába eső madarak száma jelentősen nőtt az idő elörehaladtával $\left(\mathrm{R}^{2}=0,5135\right)$. A testtömeg és az idő között sem volt korreláció $\left(\mathrm{R}^{2}=0,01\right)$ (11. ábra). A madarak testzsírjának mediánja $1(\mathrm{SD}=1,5)$, míg átlagos testtömege 9,2 g $(\mathrm{SD}=1,44)$ volt. A legtöbb madarat (a teljes fogás $51,3 \%$-a) a bokros élőhelyen álló hálók fogták. 


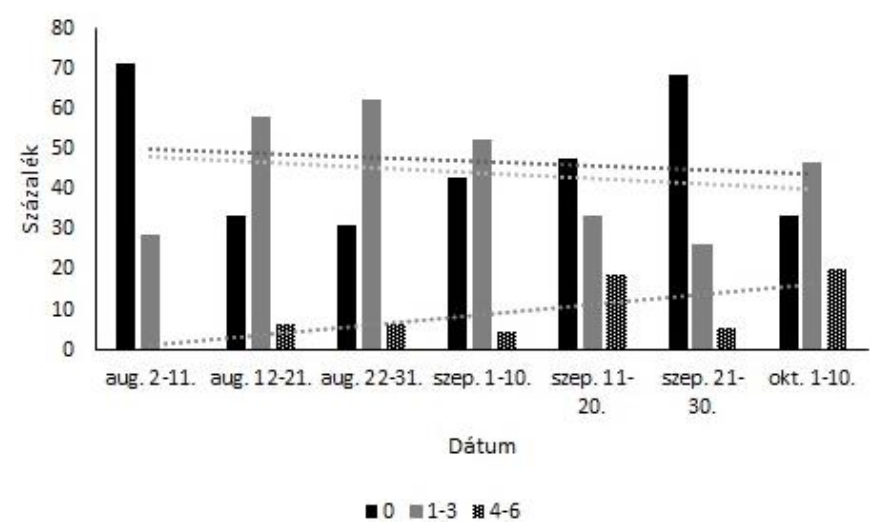

12. ábra. A fitiszfüzike testzsírjának időbeli változása Hódmezővásárhelyen az őszi vonulási időszakban.

Figure 12. Changes of fat score values related to the date in Willow Warblers during autumn migration in Hódmezővásárhely.

\section{Terepi adatok (Kevermes)}

Összesen 212 adata van a területröl a 2005-2018 közötti időszakban. 2008-2018 közötti legkorábbi és legkésőbbi adatait a 2. táblázat tartalmazza. Ennek alapján a tavaszi visszaérkezés mediánja április 9-én (legkorábban 2015. és 2018. április 4-én, legkésőbb 2017. április 23-án). A tavaszi vonulás végének mediánja a 2007-2018 közötti adatok alapján május 10-én volt (legkorábban 2018. április 22-én, legkésőbb 2010. május 21-én). A tavaszi vonulás mediánja április 20-án, csúcsa április második felében volt.

Az őszi vonulás kezdetének mediánja a 2006-2018 közötti adatok alapján augusztus 1jén volt (legkorábban 2013. július 22-én, legkésőbb 2008. augusztus 11-én). Az őszi vonulás mediánja szeptember 3-án, csúcsa augusztus vége és szeptember közepe között volt. Összel pedig az utolsó madarak elvonulásának mediánja október 12-én volt (legkorábban 2009. szeptember 19-én, legkésőbb 2016. október 18-án).

\section{Sisegö füzike}

\section{Tavasz}

Hódmezővásárhelyen 23 madarat gyürüztünk, visszafogásunk nem volt (3. táblázat). A 3 tavaszi szezon közül a 2011-es szezon fogásszáma jelentősen kisebb volt, mint a másik kettőé. A vonulás kezdetének mediánja április 19-én (legkorábban 2014. április 5-én, legkésőbb 2013. május 6-án), míg a befejezésének mediánja május 5-én volt (legkorábban 2014. április 26-án, legkésőbb 2011. május 7-én). A vonulás mediánja április 23-án volt. A vonulás csúcsa április közepén volt (13. ábra). 
A FÜZIKÉK VONULÁSA A DÉL-TISZÁNTÚLON

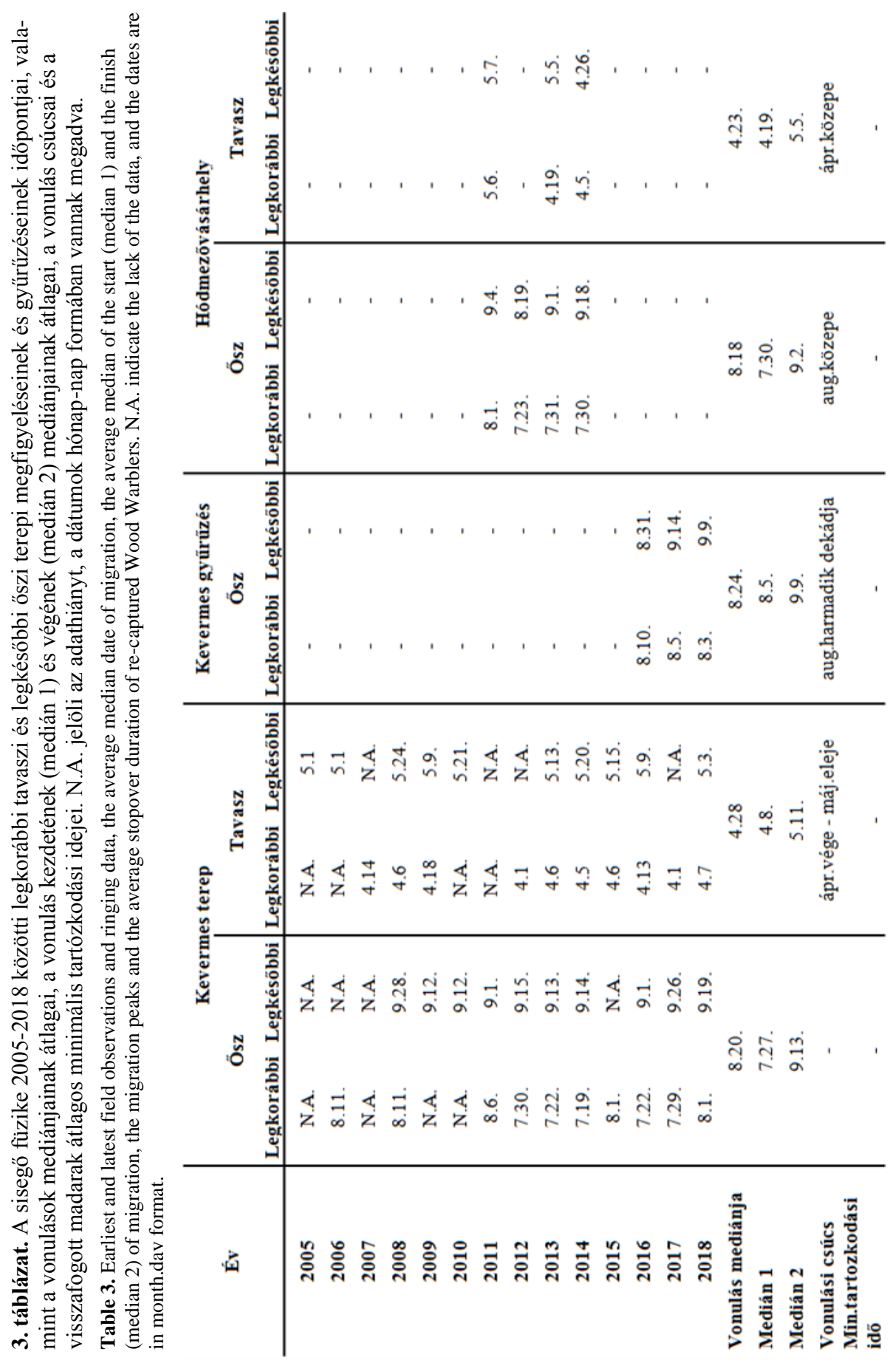


A madarak testzsírjának mediánja 1 ( $\mathrm{SD}=0,93)$, míg átlagos testtömege $10,5 \mathrm{~g}$ $(\mathrm{SD}=0,95)$ volt. Szezonon belül a testzsír értéke és az idő között összességében nem volt sem pozitív, sem negatív kapcsolat (14. ábra), és ugyanez volt igaz a testtömegre is $\left(\mathrm{R}^{2}=0,1082\right)$ (14. ábra). A legtöbb madarat (a teljes fogás $60 \%$-a) a bokros élőhelyen álló hálók fogták.

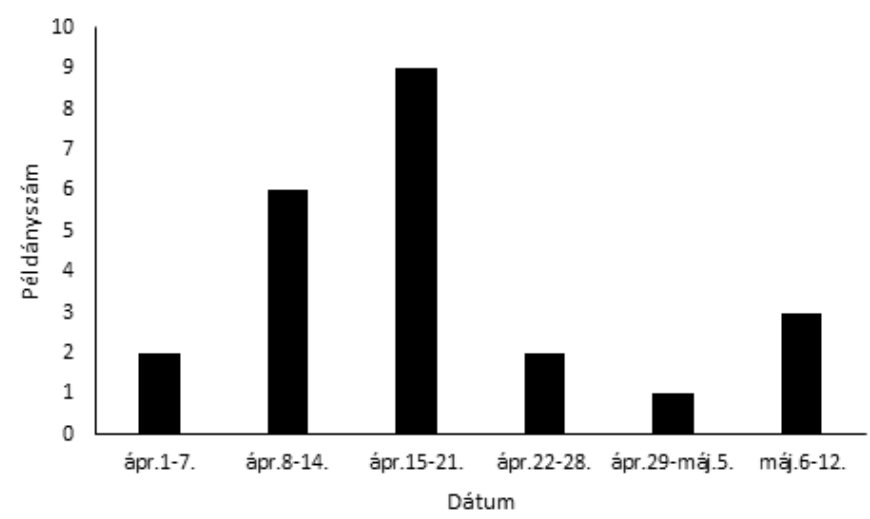

13. ábra. A sisegő tavaszi vonulásdinamikája Hódmezővásárhelyen (kumulatív adatok). Figure 13. Spring migration dynamics of Wood Warblers in Hódmezővásárhely (cumulative data).

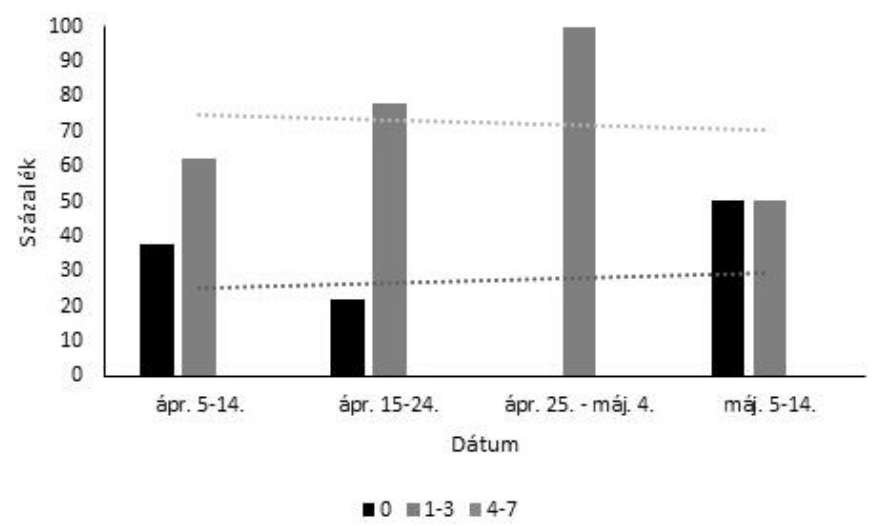

14. ábra. A sisegő füzike testzsírjának időbeli változása Hódmezővásárhelyen a tavaszi vonulási időszakban.

Figure 14. Changes of fat score values related to the date in Wood Warblers during spring migration in Hódmezővásárhely. 
Ösz

Kevermesen összesen 41 madarat gyürüztünk, visszafogásunk nem volt (3. táblázat). A három év alapján a vonulás mediánja augusztus 24 -én volt. Az első madarak megfogásának mediánja augusztus 5-én, míg az utolsó madarak fogásának mediánja szeptember 9-én volt. A vonulási csúcs a három év átlaga alapján augusztus harmadik dekádjában volt (15. ábra).

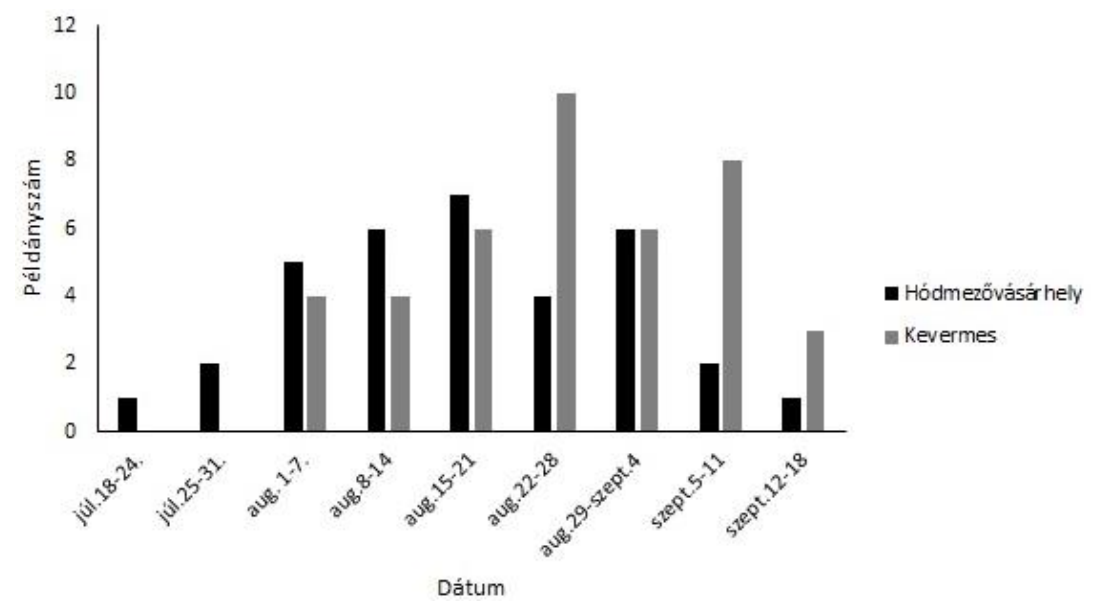

15. ábra. A sisegő füzike őszi vonulásdinamikája Hódmezővásárhelyen és Kevermesen (kumulatív adatok).

Figure 15. Autumn migration dynamics of Wood Warblers in Hódmezővásárhely and Kevermes (cumulative data).

A madarak testzsírjának mediánja $3(\mathrm{SD}=2,29)$, átlagos testtömegük $11,5 \mathrm{~g}(\mathrm{SD}=2,55)$ volt. A testzsír esetében azt figyelhettük meg, hogy a 0 és 1-3 zsírkategóriájú madarak aránya negatív korrelációt mutatott az idő múlásával $\left(\mathrm{R}^{2}=-0,512\right.$ és $\mathrm{R}^{2}=-0,9242$ sorrendben), míg a 4-7 kategóriákba tartozó madarak aránya erősen pozitívan korrelált vele $\left(\mathrm{R}^{2}=0,9546\right)$ (16. ábra). A testtömeg és az idö között nem volt korreláció $\left(\mathrm{R}^{2}=0,1819\right)$ (17. ábra).

A legtöbb madarat (a teljes fogás 43,9\%-a) a zárt erdőben álló hálók fogták.

Hódmezővásárhelyen 53 madarat gyürüztünk és 1 visszafogásunk volt (3. táblázat). A vonulás kezdetének mediánja július 30-án (legkorábban 2012. július 23-án, legkésőbb 2011. augusztus 1-jén), míg befejezésének mediánja szeptember 2-án volt (legkorábban 2012. augusztus 19-én, legkésőbb 2014. szeptember 18-án). A vonulás évenkénti mediánjainak átlaga augusztus 18 volt. A vonulás csúcsa augusztus közepén volt (15. ábra).

Az egyetlen visszafogott madár 4 napot töltött el a területen. A madarak testzsírjának mediánja $1(\mathrm{SD}=1,69)$, míg átlagos testtömege $9,7 \mathrm{~g}(\mathrm{SD}=1,76)$ volt. 


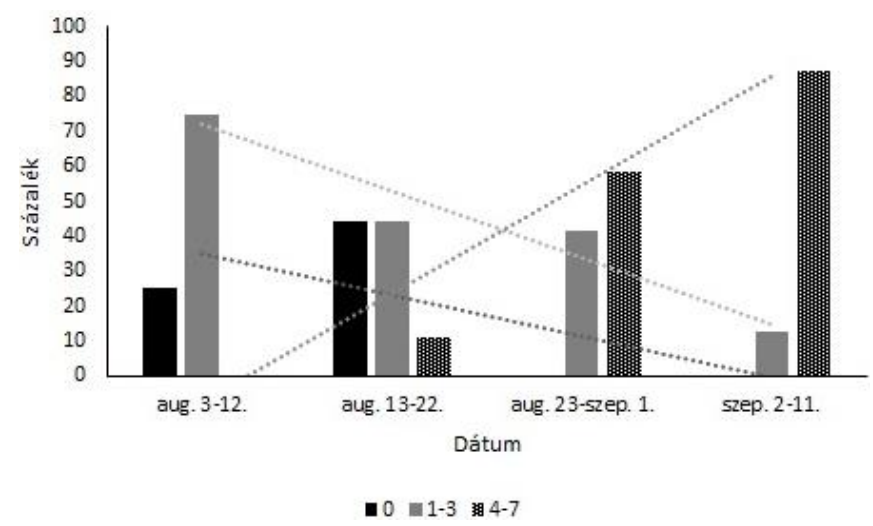

16. ábra. A sisegő füzike testzsírjának időbeli változása Kevermesen az őszi vonulási időszakban.

Figure 16. Changes in fat score values related to the date of Wood Warblers during autumn migration in Kevermes.

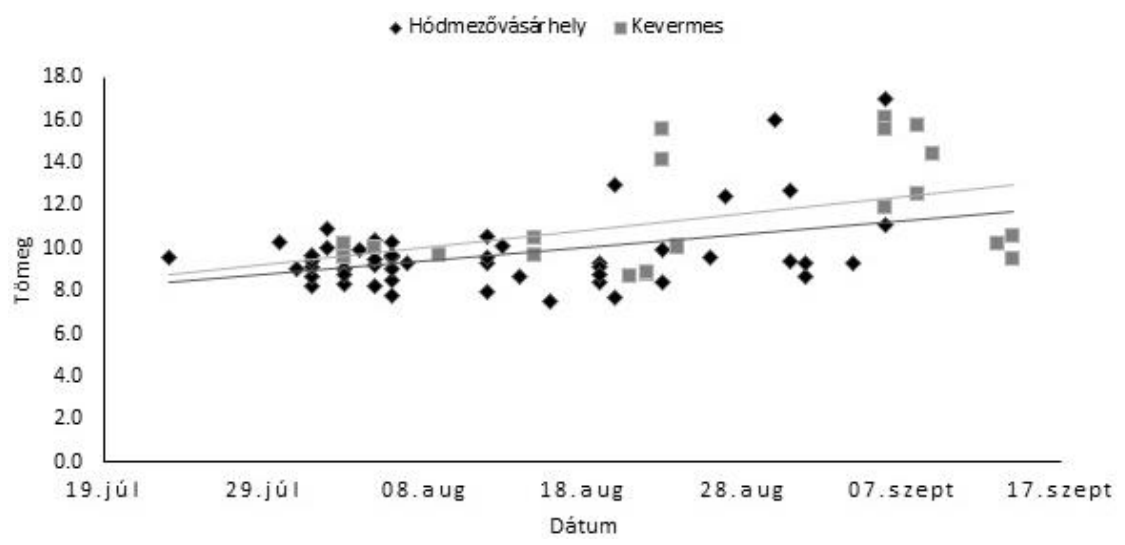

17. ábra. A sisegő füzike testtömegének időbeli változása Hódmezővásárhelyen és Kevermesen az őszi vonulási időszakban.

Figure 17. Changes of body mass related to the date in Wood Warblers during autumn migration in Hódmezővásárhely and Kevermes.

A testzsír esetében azt figyelhettük meg, hogy a 0 és 1-3 zsírkategóriájú madarak aránya gyenge negatív korrelációt mutatott az idő múlásával $\left(R^{2}=-0,0416\right.$ és $R^{2}=-0,2589$ sorrendben), míg a 4-7 kategóriákba tartozó madarak aránya erősen pozitívan korrelált vele $\left(\mathrm{R}^{2}=0,7986\right)$ (18. ábra). A testtömeg és az idő között nem volt korreláció $\left(\mathrm{R}^{2}=0,1674\right)$ (17. ábra).

A legtöbb madarat (a teljes fogás 57,4\%-a) a bokros élőhelyen álló hálók fogták. 


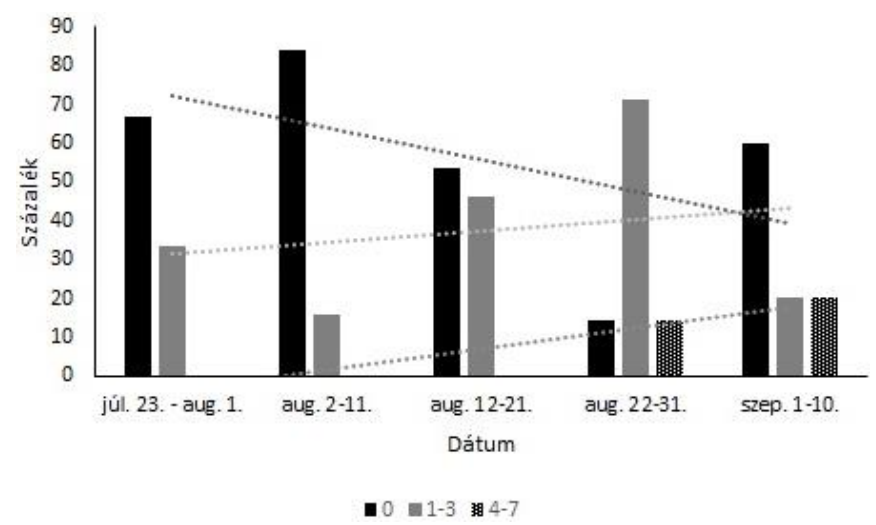

18. ábra. A sisegő füzike testzsírjának időbeli változása Hódmezővásárhelyen az őszi vonulási időszakban.

Figure 18. Changes of fat score values related to the date in Wood Warblers during autumn migration in Hódmezővásárhely.

\section{Terepi adatok (Kevermes)}

Összesen 221 adata van a területről a 2005-2018 közötti időszakban. A 2007-2018 közötti legkorábbi és legkésőbbi adatait a 3. táblázat tartalmazza. Ennek alapján a tavaszi visszaérkezés mediánja április 8-án (legkorábban 2014. április 5-én, legkésőbb 2008. április 18-án), összel pedig az utolsó madarak elvonulásának mediánja szeptember 13-án volt (legkorábban 2011. szeptember 1-jén, legkésőbb 2008. szeptember 28-án). A tavaszi vonulás végének mediánja a 2007-2018 közötti adatok alapján május 11-én volt (legkorábban 2018. május 3-án, legkésőbb 2008. május 24-én). A tavaszi vonulás mediánja április 28-án, csúcsa április végén és május elején volt. Egy esetben költési időben is észleltem a fajt (2013. június 08). Az őszi vonulás kezdetének mediánja a 2011-2017 közötti adatok alapján július 27-jén volt (legkorábban 2013. és 2016. július 22-én, legkésőbb 2011. augusztus 6-án). Az őszi vonulás mediánja augusztus 20 -án volt, határozott csúcsa nem volt, a madarak augusztus eleje és szeptember eleje között egyaránt nagy számban vonultak át a területen.

\section{Értékelés}

A Magyarországon fészkelő füzikefajok vonulását több aspektusból is vizsgálták az elmúlt évtizedekben. A három faj közül a csilpcsalpfüzike a leggyakrabban fogott faj a hazai gyürüzőtáborokban, ezért a legjobban ennek a vonulását ismerjük. A tojók és a hímek közt, ill az északibb és délibb populációk között eltérés mutatkozik a szárnyhossz tekintetében (TIAINEN 1982, TIAINEN \& HANSKI 1985, CsÖRGÖ \& LÖVEI 1986, MARCHETTI et al. 1995). Mivel a Kárpát-medencébe az északi madarak csak viszonylag kis egyedszámban jutnak be vonulásuk során, ezért a gyürüzéskor megfogott egyedek biometriai adataiból (szárny- és 
farokhossz) statisztikai módszerekkel könnyen meg lehet határozni azok ivarát (HARNOS \& CSÖRGÖ 2011). Az ehhez hasonló biometriai vizsgálatok mellett több hazai gyürüzőállomáson is készültek vonulást leíró tanulmányok, így például Tömördön (GYURÁCZ \& BÁNHIDI 2008, KISS et al. 2016) vagy éppen Ócsán (HARNOS \& CSÖRGÖ 2011). A sisegő füzike és a fitiszfüzike vonulását MIKLAY \& CsÖRGÖ (1991) írták le, újabb adatokat pedig a Magyar Madárvonulási Atlaszban találhatunk (GYURÁCZ \& CSÖRGÖ 2009b, 2009c). Az általunk elvégzett kutatómunka eredményeit ezekkel a munkákkal tudjuk összehasonlítani.

\section{Csilpcsalpfüzike}

Az intenzív őszi vonulás a csilpcsalpfüzike esetén mindkét gyürüzőhelyen szeptember 20-22. között kezdődött el, ami egyértelmüen későbbre esik, mint amit Ócsán, ill. Tömördön kaptak a kutatók (HARNOS \& CSÖRGÖ 2011, GYURÁCZ \& BÁNHIDI 2008, sorrendben). A terepi adatok azonban már szeptember elejétöl kezdve intenzív vonulást mutattak Kevermesen, amelyek a megfigyelt madarak tömegességéböl adódóan nem lehetettek a helyi állomány tagjai. A háttérben álló ok nem ismert, de talán azzal magyarázható, hogy szeptember első felében még nincs annyi egyed, hogy abból a hálókban is nagy számban akadjon meg, mivel a madarak fóként a magasabb lombkoronában mozoghatnak. Az augusztusban és szeptember első felében fogott madarak száma mindkét helyen alacsony volt, aminek oka egyértelmüen az, hogy konkrétan egyik területen sem költ a faj, a néhány fogási adat pedig a közeli állományok tagjaira vonatkozhat. Meg kell azonban jegyezni, hogy amíg Kevermesen és térségében kifejezetten ritka fészkelőnek számít (Bozó 2017), Hódmezővásárhely környékén (főként a Tisza árterében) kifejezetten gyakori, így talán alátámasztható az a megállapítás, miszerint a fiatalok nem végeznek jelentősebb diszperziós mozgást a fészekböl történő kirepülésük után (GYURÁCZ \& CSÖRGÖ 2009a). A vonulás mediánja hasonló értékeket mutat mind a négy állomás esetén. Az intenzív vonulás átlagos befejezése Kevermesen és Hódmezővásárhelyen is október 20. környékére esett, míg az utolsó madarak eltűnésének dátuma a standard gyürüzések befejezése közti eltérés miatt október vége és november közepe között változott. A terepi adatok alapján november elején tủnnek el a területről, így összességében ez beleillik az országos mintázatba, akárcsak a szeptember vége és október közepe közé eső vonulási csúcs is (GYURÁCZ \& CsÖRGÖ 2009a). A fogott madarak száma Hódmezővásárhelyen és Kevermesen sem tért el jelentősen a vizsgálati években, aminek hátterében az állhat, hogy az itt átvonuló populáció stabil, sem csökkenés, sem növekedés nem tapasztalható. A visszafogott madarak aránya Kevermesen jóval magasabb volt, mint Hódmezővásárhelyen, de az irodalomban leírtakkal ellentétben ez az arány alig különbözött az évek között (GYURÁCZ \& CSÖRGÖ 2009a). Az irodalmi adatokhoz hasonlóan ugyanakkor Kevermesen is csak egy évben haladta meg kevéssel a 15\%-os értéket ez az arány (GYURÁCZ \& CSÖRGÖ 2009a). A rendkívül alacsony hódmezővásárhelyi visszafogási arány hátterében talán a kedvezőtlenebb táplálkozási lehetőségek állhatnak, ugyanakkor az élőhely sok tekintetben hasonló volt a kevermesi területhez, így a gyorsabb vonulás az eltérő vonulási útvonal következménye is lehet. Elképzelhető ugyanis, hogy a Tisza-menti területeken jóval több alkalmas táplálkozó- és pihenőhely áll rendelkezésükre a madaraknak, így ök már korábban feltöltötték energiakészleteiket. Ellenben a Kevermesen átvonuló madarak főként agrárterületeket érintenek útjuk során, a jó minőségü táplálkozóhelyek száma korlátozott, így hosszabb időre van szükségük egyegy alkalmas élőhelyen. Az augusztusban gyürüzött madarak hosszabb időt töltöttek mind- 
két területen, mint a szeptember vége és október vége közötti időszakban, ami a helyi állományok jelenlétét igazolja a korai időszakokban. A madarak zsírkategória értékei mindkét területen nagyon alacsonyak voltak, ugyanakkor Kevermesen és Hódmezővásárhelyen is szignifikánsan nőtt a madarak testzsír értéke szezonon belül az idő előrehaladtával. Ez a Kárpát-medencében, ill. az északi országokban fészkelő állományok eltérő vonulási időzítésén alapulhat, hiszen a nálunk később átvonuló északi példányok nagyobb energiaraktárakkal rendelkeznek (GYURÁCZ \& CSÖRGÖ 2009a). A testtömeg értékek ugyanakkor csak nagyon gyenge pozitív korrelációt mutattak az idő múlásával, tehát ha finomabb és sokkal objektívebb skálán vizsgáljuk a madarak kondícióját, akkor ez a megállapítás már csak részben igaz. A visszafogott madarak testzsírja és testtömege nem változott az idő előrehaladtával, hasonlóan a tömördi adatokhoz (GYURÁCZ \& CSÖRGÖ 2009a). Mindkét vizsgálati helyen a nyíltabb élőhelyeken fogtuk a legtöbb példányt, Kevermesen pedig az is látszik, hogy a csatorna a csilpcsalpfüzike esetében is fontos vonulási folyosóként funkcionál összel (Bozó et al. 2017).

Tavasszal később kezdődik a vonulása, mint az ország más részein és ezt mind a gyürüzési, mind a terepi adatok alátámasztják. Hasonló eltérés mutatkozik a vonulás befejezésében is, hiszen Kevermesen és Hódmezővásárhelyen is csak április végére tüntek el az átvonuló egyedek. Ugyanakkor az április eleji vonulási csúcs időzítése megegyezik az országos átlaggal (CsÖRGÖ et al. 1991). A madarak testzsírja ekkor is nőtt az idő elörehaladtával, amit éppúgy eredményezhetett a különböző populációk eltérő vonulási időzitése, mint az alacsony mintaelemszám.

A faj ma már egyre több helyen és egyre nagyobb számban telel át hazánkban nádasokban, meleg vizű csatornák mellett (a szerzők személyes megfigyelése), a vizsgálati területeken ezzel szemben csupán egyetlen téli adata ismert. Ez azért rendkívül érdekes, mert Hódmezővásárhelyen a Hódtói-csatorna városi szakaszán minden évben rendszeresen áttelel néhány példány. A háttérben az állhat, hogy ezek a madarak ragaszkodnak a táplálékban gazdag nádasokhoz, ezért nem kóborolnak el más területre, Kevermesen pedig alapvetően nincs a faj áttelelésére alkalmas élőhely.

A hímek és tojók, ill. a különböző alfajok vonulásának vizsgálatához a megfelelő mintaelemszám még nem áll rendelkezésre.

\section{Fitiszfüzike}

A fitiszfüzike egyik vizsgálati területen sem költ, vonuláskor viszont gyakori. Az őszi vonulás mindkét helyen augusztus elején indult el. Hódmezővásárhelyen néha már ekkor is a szokásosnál nagyobb számban vonultak a madarak, általában viszont itt is csak szeptember elején vette kezdetét az intenzív vonulás, ami megegyezik az országos átlaggal (MIKLAY \& CsÖRGÖ 1991) és a tömördi adatokkal (GYURÁCZ \& BÁNHIDI 2008). A csúcs időszaka azonban némi eltérést mutatott a két terület között, ami akár azt is jelezheti, hogy más populációk, eltérő időzítéssel vonulnak át a két területen. Az utolsó madarak eltünésének dátuma október közepére esik, október harmadik feléböl egyetlen adata sincs, ami szintén egybevág az irodalomban leírtakkal (GYURÁCZ \& CSÖRGÖ 2009b; GYURÁCZ \& BÁNHIDI 2008). A terepi adatok alapján fontos kiemelni, hogy már július utolsó harmadában felbukkannak vonuló egyedek, amelyek valószínüleg közelebbi állományokból származó fiatalok lehetnek. A visszafogott madarak aránya mindkét területen alacsony volt, és jelentősebb zsírfelhalmozás sem volt megfigyelhető a később visszafogott madarak esetén, így 
valószínúleg egyik terület sem számít fontos táplálkozó- és pihenőhelynek. Kevermesen ugyanakkor 2018-ban jóval nagyobb arányban fogtuk vissza a faj egyedeit, így akár évek közötti különbségek sem kizárhatók e tekintetben. Ebben az évben az előző két év átlagához képest megduplázódott a fogásszám is. Ez a jelentős különbség az aktuális évi költési siker miatt alakulhatott ki, de az sem kizárt, hogy egy környékbeli állomány megerősödése áll a hátterében. A madarak testzsírja és testtömege sem változott az idő elörehaladtával. Ez, ill. a rövid minimális tartózkodási idő is megerösíti azt a feltételezést, hogy a tölünk északra fészkelő populációk csak kis számban vonulnak át nálunk (GYURÁCZ \& CSÖRGÖ 2009b). A legtöbb madarat a nyíltabb élőhelyeken fogtuk, éppúgy, mint a csilpcsalpfüzike esetében, így a magyarázatok is megegyeznek az ott ismertetettekkel (lásd fentebb).

Tavasszal mindkét területen április első felében indult a vonulás és május közepéig tartott, ami beleillik az országos mintázatba (GYURÁCZ \& CSÖRGÖ 2009b). Egyetlen, május 21-i kevermesi adata alapvetően kilóg az általános vonulási mintázatból, így akár az sem kizárható, hogy alkalmilag költhet is bizonyos idősebb erdőkben, de ez jelenleg nem bizonyított (BOZÓ 2017).

A hímek és tojók, ill. a különböző alfajok vonulásának vizsgálatához a megfelelő mintaelemszám még nem áll rendelkezésre.

\section{Sisegö füzike}

Bizonyítottan a sisegő füzike sem költ a két területen, ugyanakkor a Madáratlasz Program térképein Hódmezővásárhely és Kevermes környékén is több UTM négyzetben is lehetséges, ill. valószínü fészkelőként tüntették fel a megfigyelők a fajt (MAGYAR MADÁRTANI ÉS TERMÉSZETVÉDELMI EGYESÜLET 2018). Kevermesen 2013-ban nagy valószínüséggel költött a faj egy telepített, idős nemesnyarasban (BozÓ 2017). Vonuláskor mindkét területen a legkisebb számban fogott faj volt a füzikék közül, ami megegyezik az országos adatokkal (GYURÁCZ \& CSÖRGÖ 2009c). Mind a gyürüzési, mind a terepi adatok azt mutatják, hogy július végén - augusztus elején elkezdik az öszi vonulást, míg az utolsó egyedeket szeptember közepén észleltük, ami szintén megegyezik CsÖRGÖ \& MIKLAY (1991) eredményeivel. A csúcs időzítése ugyanakkor eltérést mutat a tömördi adatoktól, hiszen az ott augusztus első, és nem második felében volt (GYURÁCZ \& BÁNHIDI 2008). Ez jelezheti azt, hogy nagyobb földrajzi távolságok esetében változhat a vonulás időzítése, de adódhat abból is, hogy Tömörd északabbra helyezkedik el, mint Kevermes és a madarak később érnek el a délebbi területekre. A terepi adatok ennél a fajnál is azt mutatják, hogy a gyürüzési csúcs előtt is nagy számban mozogtak a madarak Kevermesen, aminek hasonló magyarázata lehet, mint a csilpcsalpfüzikénél. A három faj közül ennek volt a legnagyobb az átlagos testzsírja, de itt is ki kell emelni, hogy a Hódmezővásárhelyen fogott egyedek jóval kevesebb zsírtartalékkal rendelkeztek, mint a kevermesiek. Ennek hátterében az eltérő vonulási stratégia állhat, ahogy azt a csilpcsalpfüzike esetében fentebb részleteztük. A rendkívül kevés visszafogás gyors vonulásra utal. Sem a testzsír, sem a testtömeg nem változott az idő előrehaladtával. Hódmezővásárhelyen az előzö két fajhoz hasonlóan nagyrészt a nyíltabb, bokros élőhelyeken fogtuk, ugyanakkor Kevermesen a zárt erdőben akadt meg a legtöbb. Ez azért érdekes, mert egy korábbi vizsgálat során kiderült, a területen átvonuló fajok többsége kerülte ezt az élőhelyet (Bozó et al. 2017), de a sisegő füzike minden bizonnyal megfelelő mennyiségü rovartáplálékot talál magának az ezüstfás lombkoronájában is. 
A tavaszi vonulás a terepi és a gyürüzési adatok alapján is április eleje és május közepe között zajlott, ami hasonló az irodalomban közölt adatokhoz (GYURÁCZ \& CSÖRGÖ 2009c). A május 24-i megfigyelés későinek tünik, de 2008-ban ezt követően nem került elő éneklő madár a területről, így ez az adat még valószínüleg vonuló egyedre vonatkozik. A visszafogások hiánya gyors vonulásra utal. A hódmezővásárhelyi adatok alapján a madarak nagyobb zsírtartalékkal rendelkeztek tavasszal, mint ősszel, ami lehetővé teszi a gyors vonulást, ill. azt jelzi, hogy a madarak délebbre töltötték fel energiaraktáraikat.

Köszönetnyilvánítás. Köszönetünket fejezzük ki mindazoknak, akik az évek során segédkeztek a terepi adatgyüjtésben, különösképpen a hódmezővásárhelyi és kevermesi gyürüzőállomások önkénteseinek. A kutatást a Nemzet Fiatal Tehetségeiért Ösztöndíj pályázata támogatta.

\section{Irodalomjegyzék}

Alström, P., Rheindt, F. W., Zhang, E., Zhao, M., Wang, J., Zhu, X., Yin Gwee, HaO, Y., Ohlson, J., Jia, C., Prawiradilaga, D. M., Ericson, P. G. P., Lei, F. \& Olsson, U. (2018): Complete species-level phylogeny of the leaf warbler (Aves: Phylloscopidae) radiation, Molecular Phylogenetics and Evolution 126: 141-152. https://doi.org/10.1016/j.ympev.2018.03.031

BorвÁTH, E. (2015): Énekesmadár közösség vizsgálata egy degradált élőhelyen. Szakdolgozat, Szegedi Tudományegyetem, Szeged, $38 \mathrm{pp}$.

BozÓ, L. (2017): Kevermes madárvilága. Dél-békési Természetvédelmi és Madártani Egyesület, Kevermes, $121 \mathrm{pp}$.

BozÓ, L., BozÓNÉ BORBÁTH E. \& TAR, L. (2017): A fasorok és vízelvezető csatornák jelentősége a madárvonulásban. Természetvédelmi Közlemények 23: 1-13.

Clement, P. (2018a): Common Chiffchaff (Phylloscopus collybita). In: DEl Hoyo, J., ElliotT, A., Sargatal, J., Christie, D. A. \& DE Juana, E. (eds.): Handbook of the Birds of the World Alive. Lynx Edicions, Barcelona, World Wide Web electronic publication. https://www.hbw.com/node/58861 (megtekintés 2018 július 3.)

Clement, P. (2018b): Willow Warbler (Phylloscopus trochilus). In: DEl Hoyo, J., Elliott, A., Sargatal, J., Christie, D.A. \& DE Juana, E. (eds.): Handbook of the Birds of the World Alive. Lynx Edicions, Barcelona, World Wide Web electronic publication. https://www.hbw.com/node/58860 (megtekintés 2018 július 3.)

Clement, P. (2018c): Wood Warbler (Phylloscopus sibilatrix). In: DEL Hoyo, J., Elliott, A., Sargatal, J., Christie, D.A. \& DE Juana, E. (eds.): Handbook of the Birds of the World Alive. Lynx Edicions, Barcelona, World Wide Web electronic publication. https://www.hbw.com/node/58868 (megtekintés 2018 július 3.)

CSÖRGÖ, T. \& LÖVEI, G. (1986): Egy fészkelő csilpcsalpfüzike (Phylloscopus collybita) populáció szárnyalakjának jellemzése [Wing shape characteristics of a breeding population of the Chiffchaff (Phylloscopus collybita)]. In: MolnÁR, Gy. (szerk.): Magyar Madártani és Természetvédelmi Egyesület II. Tudományos Ülése. MME, Szeged, pp. 155-158.

CSÖRGÖ, T., MiKLAY, GY. \& CZEGLÉDI, Zs. (1991): Honnan származnak a Kárpát-medencén átvonuló csilcsalp füzikék (Phylloscopus collybita)? In: GYURÁcz, J. (szerk.): A Magyar Madártani és Természetvédelmi Egyesület III. Tudományos Ülése. MME, Szombathely, pp. 123-131. 
GILL, F. \& DONSKER, D. (eds.) (2016): IOC World Bird List (v 6.2). World Wide Web electronic publication. www.worldbirdnames.org (megtekintés 2018 július 3.) https://doi.org/10.14344/IOC.ML.6.2

GyurÁCZ, J., BÁNHIDI, P. \& GABNAI, H. (2004): A csilpcsalpfüzike (Phylloscopus collybita) öszi vonulásának dinamikája Tömördön. Cinege 9: 26-28.

GyURÁCZ, J. \& BÁNHIDI, P. (2008): Dynamics and Spatial Distribution of Migratory Birds: Results of Bird Ringing Project of Tömörd Bird Observatory 1998-2007. University of West Hungary, István Chernel Ornithological and Nature Conservation Society, Szombathely, 144 pp.

GyurÁCZ, J. \& CsÖrgÖ, T. (2009a): Csilpcsalpfüzike. In: CsÖRGÖ, T., KARCZA, Zs., Halmos, G., MAgyar, G., GyurÁcz, J., SzÉP, T., BANKOvics, A., SCHMidT, A., SchmidT, E. (szerk.): Magyar madárvonulási atlasz. Kossuth Kiadó, Budapest, pp. 521-524.

GyurÁCZ, J. \& CsÖRGÖ, T. (2009b): Fitiszfüzike. In: CsÖrGÖ, T., KARCZA, Zs., Halmos, G., MAGYAR, G., GYURÁCz, J., SzÉP, T., BANKOvics, A., SCHMidT, A., SCHMIDT, E. (szerk.): Magyar madárvonulási atlasz. Kossuth Kiadó, Budapest, pp. 526-527.

GYurÁCZ, J. \& CsÖRGÖ, T. (2009c): Sisegő füzike. In: CsÖRGÖ, T., KARCZA, Zs., HALMOS, G., MAGYAR, G., GYURÁCz, J., SzÉP, T., BANKOvics, A., SCHMidT, A., SCHMIDT, E. (szerk.): Magyar madárvonulási atlasz. Kossuth Kiadó, Budapest, pp. 519-520.

HAMMER, Ø., HARPER, D. A. T. \& RYAN, P. D. (2001): PAST: Paleontological statistics software package for education and data analysis. Palaeontologia Electronica 4(1): 9 pp.

HARASZTHY, L. (1998): Sisegő füzike. In: HARASzTHY, L. (ed.): Magyarország madarai. Mezőgazda Kiadó, Budapest, pp. 320-321.

HARNOS, A. \& CSÖRGÖ, T. (2011): Ivarmeghatározás biometriai adatok alapján - esettanulmány a csilpcsalpfüzikére [Sex determination based on biometrical data-a case study for the Chiffchaffs]. Ornis Hungarica 19(1-2): 40-52.

Kiss, C., BÁnhidi, P., Lukács, Z., Kalmár, S., Winkler, D. \& Gyurácz, J. (2016): A csilpcsalpfüzike (Phylloscopus collybita Vieillot, 1817) populációdinamikájának vizsgálata a tömördi madárvártán a 2000-2014-es időszakban. Nyugat-Magyarországi Egyetem Savaria Egyetemi Központ Tudományos Közleményei 16(1): 191-202.

LövEI, G. L. (1983): Wing shape variations of Chiffchaffs on autumn migration in Hungary. Ringing \& Migration 4(4): 231-236. https://doi.org/10.1080/03078698.1983.9673811

MAgYAR MAdÁRTANI ÉS TERMÉSZETVÉDELMI EgYESÜLET (2018): Magyarország madarai: Sisegő füzike. World Wide Web electronic publication. http://www.mme.hu/magyarorszagmadarai/madaradatbazis-physib (megtekintés 2018 július 9.)

MarchetTi, K., Price, T. \& Richman, A. (1995): Correlates of wing morphology with foraging behaviour and migration distance in the genus Phylloscopus. Journal of Avian Biology 26(3): 177-181. https://doi.org/10.2307/3677316

Miklay, Gy. \& CsÖRGÖ, T. (1991): A fitiszfüzikék (Phylloscopus trochilus) és sisegő füzikék (Ph. sibilatrix) vonulásdinamikája és szárnymorfológiai jellemzői. In: GYURÁCZ, J. (szerk.): A Magyar Madártani és Természetvédelmi Egyesület III. Tudományos ülése. MME, Szombathely, pp. 140148.

MME NOMENCLATOR BIZOTTSÁG (2008): Magyarország madarainak névjegyzéke. Nomenclator Avium Hungariae. (An annotated list of the birds of Hungary). Magyar Madártani és Természetvédelmi Egyesület, Budapest, 278 pp.

MócsÁn, A. (2008): A csilpcsalpfüzike (Phylloscopus collybita) vonulásdinamikája a Kaszonyi-hegy Természetvédelmi Területen. Szakdolgozat, Debreceni Egyetem, 38 pp. 
Tiainen, J. (1982): Ecological significance of morphometric variation in three sympatric Phylloscopus warblers. Annales Zoologici Fennici 19(4): pp. 285-295.

TIAINEN, J. \& HANSKI, I. K. (1985): Wing shape variation of Finnish and central European willow warblers Phylloscopus trochilus and chiffchaffs P. collybita. Ibis 127(3): 365-371.

VARGA, F. (1998a): Csilpcsalpfüzike. In: HARASZThy, L. (ed.): Magyarország madarai. Mezőgazda Kiadó, Budapest, pp. 319-320.

VARGA, F. (1998b): Sisegő füzike. In: HaraszThy, L. (ed.): Magyarország madarai. Mezőgazda Kiadó, Budapest, pp. 318-319. 


\section{Migration of Common Chiffchaff (Phylloscopus collybita), Willow Warbler (Ph. trochilus) and Wood Warbler (Ph. Sibilatrix) in the South-Tiszántúl (SE-Hungary) \\ LÁSZLÓ BOZÓ ${ }^{1}$ \& ERNA BOZÓNÉ BORBÁTH² \\ ${ }^{1}$ Department of Systematic Zoology and Ecology, Eötvös Loránd University, Pázmány P. sétány 1/C, H-1117 Budapest, Hungary E-mail: bozolaszlo91@gmail.com \\ ${ }^{2}$ South Békés Nature Conservation and Ornithological Society, Jókai u. 61, H-5744 Kevermes, Hungary}

\section{ÁLLATTANI KÖZLEMÉNYEK (2018) 103(1-2): 47-72.}

Abstract. We studied the migration of leaf warblers at two study sites in the Southern part of Tiszántúl. We collected and used bird ringing and field observation data from the period 2005-2018, and our results were compared with publications of other Hungarian ringing stations. Our results show that Wood Warblers and Willow Warblers start their migration later than birds migrating in more northerly located places. There were differences between the migration strategies of birds from the two study sites, probably due to differences in feeding opportunities at the two migratory ways. Comparing the ringing and field observation data we found large differences in the intensity of migration. The studied species basically used similar open habitats during migration, however, Wood Warblers were more often found in closed forests than the other two species.

Key words: songbird migration, Hódmezővásárhely, Kevermes, bird ringing. 